\title{
The Millennials: Insights to Brand Behavior for Brand Management Strategies
}

\author{
Babijtchouk Olga ${ }^{1}$, Dames D. David ${ }^{1}$, Gehan S. Dhameeth ${ }^{1}$, Sleezer Adam ${ }^{1} \&$ Smith Elliott ${ }^{2}$ \\ ${ }^{1}$ Center for Business and Entrepreneurship, Wells College, Aurora, New York, USA \\ ${ }^{2}$ Department of Psychology, Wells College, Aurora, New York, USA \\ Correspondence: Gehan S. Dhameeth, Assistant Professor of Business, Center for Business and Entrepreneurship, \\ Wells College, Aurora, New York 13026, USA. Tel: 1-315-702-3292.
}

Received: June 1, 2018

doi:10.5430/jms.v9n3p1
Accepted: June 17, 2018

Online Published: June 20, 2018

URL: https://doi.org/10.5430/jms.v9n3p1

\begin{abstract}
Millennial generation has surpassed generation $\mathrm{X}$ and Baby Boomers in terms of population (market) size and standout to be the largest market segment. This demographic change will undoubtedly be an opportunity for marketing and brand managers to reach, acquire, and retain Millennial market to achieve organizational profitability. Prior research has not been successful to provide a detailed understanding of Millennials and their degree of brand loyalty over prior generations. In this article, the authors used Kevin Lane Keller's work (Brand Resonance Pyramid 2009) to test the degree of brand loyalty of Millennials over prior generations and the degree of brand resonance that predicts the brand loyalty while this relationship is moderated by the generation. In addition, they determined how the elements of the brand pyramid relate to each other. In this study, the authors administered an online survey using SurveyMonkey to reach local (US) and international college/university respondents $(n=267)$ age 18 years and above. The survey was administered using a questionnaire (46 data points). Linear Regression and Partial Correlation were used for analysis. The authors find that Millennials and Generation X/Boomers are not significantly different in terms of brand loyalty, brand resonance is a strong positive predictor for brand loyalty, and finally, the relationship between brand resonance and brand loyalty is weaker for Millennials than for Generation X/Boomers.
\end{abstract}

Keywords: brands, brand loyalty, millennials, brand resonance

\section{Introduction}

Organizations that focus on establishing customer-based brand equity, with an implicit attention to the growing Millennial market will undoubtedly secure long-term profits. This generational cohort has surpassed Baby Boomers as the largest generational demographic. The concept of brand loyalty has been studied and researched by many statisticians, scholars, and marketers. Brand loyalty is defined as "a deeply held commitment to rebuy or re-patronize a preferred product/ service consistently in the future" (Howe, N., \& Strauss, W., 2000). This simply means that customers who exhibit loyalty to a brand will continue to purchase and engage with that particular brand more so than any other brand. Recently, millennials (a generation established between the 1980's-2000) (Raut, 2015), and (the generational cohort after generation X) has become the leading population within the United States (DeVaney, 2015). Even more so, this cohort has increased in population not just in the United States but throughout the world and is becoming a progressively important demographic for businesses to not only make customers out of, but a loyal customer. It is proven that loyal customers have a higher tendency to purchase products from their preferred brands, are more likely to advocate their favored brands, and are less sensitive to increases in price (Doster, 2013). This is extremely important as this helps increase a brand's profit margins, sales, and advertising through word-of-mouth. But the big question is; are millennials brand loyal, and on what basis are they loyal? Research indicates that brand loyalty can be determined based off of demographic indicators such as: age, income, gender, etc. However, more so than these general gauges, there are specific degrees of brand loyalty (Mostert, P. G., Petzer, D. J., and Weideman, A.,2016). To date, scholars have argued for demographics, psychographics, and other related sociocultural factors that influence the degree of brand loyalty among the millennials (DeVaney, 2015; Lotfizadeh, F., and Lotfizadeh, 2015; Von Freymann, J. W., 2006; Brakus, 2009; and Liu-Thompkins, 2013). However, the body of literature has not been successful to provide the underpinnings of building brand resonance that lead to millennials' brand loyalty. As such, this paper centers on the empirical groundings of Kevin Lane Keller's Brand Resonance Pyramid (2009) to investigate the 
hierarchical influence of the factors (salience, imagery, performance, feelings, judgements, and resonance) that drive brand resonance of millennials. These specific degrees of influence as well as multitude of other variables will be examined and evaluated to view if these elements can directly impact the brand loyalty of millennials. Given the above situation and the interest in developing a better understanding of the context, it is the interest of the authors to address the following questions in this study;

Q1: Are Millennials Less Brand Loyal than previous generations?

Q2: Does Brand Resonance predict Brand Loyalty and does Generation moderate the relationship?

Q3: How are the blocks of the Brand Resonance pyramid related to each other and are our data consistent with Keller's model?

Q4: Do our findings suggest a set of strategies for increasing Brand Resonance and Brand Loyalty?

\section{Theoretical Frame}

In this study, we profile millennials based on the profiling grounded in the body of literature. Additionally, brand loyalty and brand resonance have been described and defined.

\subsection{Millennials}

According to the U.S. Bureau of Labor Statistics (2014), millennials are defined as people born after 1980. Based on the scholarly work established so far about millennials, the results have been mixed and not been able to clearly define their profiles successfully (Van der Lans, R., Pieters, R., \& Wedel, M.,2008)." Millennials may have a realistic views and expectations of the world, but they still expect advancements in life. "Although millennials have realistic expectations as they enter the workforce, they also anticipate receiving strong skill development opportunities and accelerated career advancement (Ng, Schweitzer, and Lyons, 2010). DeVaney (2015) defines Millennials as they are "today within society" referring to studies and observations from other scholars. Topics such as Millennials in the workplace (DeVaney,2015), Millennials mindsets (Bucic, T., Harris, J., and Arli, D.,2012), and Millennials in their communities (Solomon, M., 2016) are discussed. Solomon (2016) and DeVaney (2015) profile millennials as a social generation that expects technology to simply work. They are collaborative and cooperative, looking for adventure and passionate about values. However, their work has not been supported with empirical evidence. Based on a cross-sectional survey study conducted by Balajik and Indradevi (2015), they argue that millennials are complex individuals who are part self-centered, part-social human beings.

According to Smilansky (2016), millennials are described as a cost-conscious generation. This can be attributed to the housing market crash in 2005. This can be attributed to the housing market crash in 2005along with the recession in 2008 that left many businesses and people in financial shambles. Smilansky further remarks that paying attention to peer input and online reviews, offer subscription models for products and services, crafting meaningful brands causes rather than emphasizing diversion or boost of status, be transparent and honest about products and creating them, and investing in social influencers and collaborate with them to shape marketing efforts would be the way to attract millennials. Solomon (2016), references five key traits that millennials exhibit. 1. Millennials expect technology to simply work 2. Millennials are a very social generation which is a key influence through the digital age. 3. They collaborate and cooperate, 4 . They are looking for adventure, and lastly are passionate about values. When combining these along with what DeVaney (2015) suggests, a cohesive argument/reasoning can be made together to form a well written description about millennials, and how they should be perceived and worked towards management of marketing. When shared values are present, Millennials are to be more loyal to that brand, but not totally loyal due to their positive reaction to job control. This is because authority and conformity do not mix well with millennials, so being tied down to one brand would not be a positive result among millennials.

Stocchi, L., Driesener, C., and Nenycz-Thiel, M. (2015) remark that millennials are a pampered generation that expects everything to come to them. "Criticism of the millennial generation also has been common from human resource management consultants and in the popular media. Millennials are laden with trophies just for participating and they think business-as-usual ethic is for the birds" (Howe, N., \& Strauss, W., 2000). Some motivating factors such as: recognition, job control, shared core values, work itself, work schedule, flexibility, satisfactory pay rate have been influential in determining why the millennials are the way they are in workplaces. Putre (2013) argues that forced changes within the workplace were necessary for establishing a modern working environment in the future. Despite the importance of the argument in today's business context, the study does not provide an empirical framework. However, this article is in line with some arguments of scholars, who contend that the change is a must in workplace for millennials to perform their work. Considering Millennials and their brand loyalty, it is important to first understand who Millennials are, and the characteristics that make them the way that they are. One of the studies 
found Millennials in the workplace, and their attitudes and particular factors that create their attitudes in the workplace. Factors such as Shared Core Values and Job Control are indications that Millennials prefer when they are in control and can feel a connection to what they are doing.

\subsection{Brand Loyalty}

Brand loyalty can be defined as a consumer's obligation to rebuy products from a favored or preferred brand consistently. This leads consumers to a future of repetitive purchase decisions from that particular brand despite the presence of other brands that can influence brand switching. (Garvey, A.M., Germann, F., and Bolton, L. E., 2016) In the modern world, becoming brand conscious and making positive choices among adolescent is increasing (Kakati, R. P., and Choudhury, S., 2013). Many consumers are selecting their brand preferences between the ages of 15 and 25 (Reisenwitz T, Gupta S., 2016). Furthermore, among young consumers, peers and the like are playing a vital role in the marketplace, this is because they make heavy influences by their purchases and choices of brands (Saddlemyer, J., and Bruyneel, S., 2016). The author further argues that patterns of brand purchasing, and behavioral brand loyalty prove to be similar to those found among Western consumers. "Broader implications about consumers include the fact that over a sequence of purchases, consumers tend to buy several brands with fairly steady habitual propensities - which mirrors experiences in the West." Based on Lotfizadeh, F., and Lotfizadeh (2015) grounded findings, Chinese consumers are not particularly brand-loyal, in the sense of exclusive loyalty, and, if anything, they are becoming less loyal. This reflects the development of Chinese consumer markets. As stated earlier, new products and new brands are being launched daily and new types of retail outlet are emerging, including convenience stores, discount chains, and online shopping. Consumers have not only become used to having many different choices, they now expect choice - in much the same way as consumers in the West. This means there are more opportunities for consumers to show patterns of divided loyalty (in the sense that consumers can exhibit loyalty to a repertoire of brands, with varying long-run propensities to buy brands in these repertoires) (Lotfizadeh, F., and Lotfizadeh, 2015). This specific phenomenon is due to the different stages of economic and retail development in the different cities: as more brands become available in inland cities, possibly through a trickle-down effect, there are more opportunities for consumers to exhibit divided loyalty (Lotfizadeh, F., and Lotfizadeh, 2015).

A study was conducted examining the relationships between millennial buyers and status consumption using Consumer Styles Inventory (CSI) technique. Interestingly enough, a link was established between millennials and status consumption. In fact, status consumption was a positive precursor to five of the eight CSI's shopping style characteristics. These characteristics consist of: brand consciousness, novelty and fashion consciousness, recreational and shopping consciousness, impulsive/carelessness, and habitual/brand loyalty. The characteristics of perfectionist, confused by over-choice, and price conscious were characteristics of generation Y based on this study. (Eastman, J. K., Iyer, R., and Thomas, S. P., 2013) Results propose that millennial consumers who are motivated to consume for status will utilize the shopping styles of being brand conscious, novelty/fashion conscious, recreational shoppers, impulsive shoppers, and brand loyal. The author contends that this is a critical area to analyze because the propensity to consume for status can directly impact shopping behavior. Smith K. (2016) integrated their research of past authors and consolidated traits to develop a consumer decision-making styles (CSI) list. Previous literatures on styles of buyer's behavior were based on the consumer's characteristics, ranging from rationale and quality consciousness to impulsiveness and finally to information overload (Lastovicka, 1982; Maynes, 1976). According to CSI theory (Smith K., 2016)), the eight traits that consumers exhibit are: brand consciousness, novelty and fashion consciousness, recreational and shopping consciousness, impulsive/carelessness, and habitual/brand loyalty, perfectionist, confused by over-choice, and price consciousness. Consumers who are brand conscious focus on purchasing well-known brands. (Barber, N., Dodd, T., and Ghiselli, R., 2008) Consumers who are novelty and fashion consciousness purchase with the intention of staying relevant within the current fashion trends (Barber, N., Dodd, T., and Ghiselli, R., 2008). Recreational and shopping consciousness consumers focus of consuming as an activity, or hobby put simply by Kapferer, J.-N. (2005). Impulsive/careless consumers often make spontaneous purchase decisions (Kaplan Thaler, L., and R. Koval, 2003). Habitual/brand loyal customers purchase with the intention of favoring a preferred brand. (Barber, N., Dodd, T., and Ghiselli, R., 2008) Perfectionist consumers shop with the intention of purchasing goods and services from the most superior quality (Lam, S. K., Ahearne, M., Hu, Y., and Schillewaert, N., 2010). A customer who is confused by over-choice find difficulty shopping with a surplus of options. (Yu-Ping., C., Nelson, L. D., and Ming, H., 2015) Finally, price conscious customers are concerned about the value they receive for purchasing a product, prefer buying at lower prices (Russell, B., 2015).

Eastman and Liu (2012) discovered there are generational differences in the motivation to consume for status. Millennials display higher levels of consumption for status than both Generation X and Baby Boomers. Furthermore, the author contends that in a study of young status conscious consumers, millennials tend to be likely to be affected 
by a brand's status and symbolic physiognomies, by feelings evoked by the brand and if the consumer's self-image and the brands overall image align. This simply means that millennials desire the status of a brand's products as well as a needed alignment in image. Lambert-Pandraud, R., \& Laurent, G. (2010) suggest that younger consumers spend more on branded products including status products; and Maity, M., and Gupta, S. (2016) suggests from his sample of college students, that when status-seeking consumers discover which brands convey status that they will stay with those brands for as long as the status effect lasts. Even though brand loyalty is described as a long-term relationship (Liu-Thompkins, 2013, Y., \& Tam, L., 2013), customer satisfaction is an integral ingredient and is typically a precondition for brand loyalty (Labrecque, L. I., Krishen, A. S., and Grzeskowiak, S.,2011). Mostert and his co-authors contend that customer satisfaction plays a vital role in determining brand loyalty among millennials (Mostert, 2016). However, customer satisfaction is not the only singular variable that plays a role in determining brand loyalty- relationship intention is a variable that is imperative as well. Keller, K. L. (2009) defines relationship intention as a customer's intention to build a relationship with a brand, a product or a service associated with an organization. According to Keller, K. L. (2009) it is important to invest in relationships with customers who have high relationship intentions, as they have already established a high degree of loyalty to the brand. To argue in line with the above premises, Keller contends that they are not opportunistic in their dealings with the brand, are less price-sensitive, have a long-term relationship perspective, and could ultimately be more profitably served. Furthermore, Keller, K. L. (2009) suggests that customers' relationship intentions comprise five sub-constructs: involvement, expectations, forgiveness, feedback and fear of loss of the relationship. However, customers are likely to switch to a competitor brand when they are dissatisfied (Howe, N., and Strauss, W., 2000). Regarding the influence of customer satisfaction on brands, Kellison, T. B., Yu Kyoum, K., and Magnusen, M. J.,2013) and Keller, K. L., Heckler, S. E., and Houston, M. J. (1998), found that customer satisfaction with a specific brand is essential to brand loyalty and that without it brand loyalty cannot exist.

Maity, M., and Gupta, S. argue that customers who are not members of loyalty programs are less affected by advertisements and these advertisements do not significantly affect attitudinal or behavioral loyalty (Maity, 2016). However, the authors also argue that customers who are members of LP's (loyalty programs) are more effectively impacted by attitudinal loyalty through advertisements (Maity, 2016). This article is important and relevant to our research because of the attitudes that millennials have towards advertisements. Based on research millennials are prone to skip advertisements. The information within this study could potentially be used as recommendations for brands (if loyalty is not detected among millennials) to effectively advertise and create loyal customers out of this generational cohort. According to the author, brand loyalty is categorized into behavioral loyalty and attitudinal loyalty (Mostert, P. G., Petzer, D. J., and Weideman, A., 2016). Furthermore, "the behavioral approach focuses more on the outcome rather than the motivations a consumer has when purchasing products (Keller, K. L., Heckler, S. E., and Houston, M. J., 1998). On the contrary, attitudinal loyalty focuses on the emotional or psychological explanations of brand loyalty (Doster, L., 2013). According to the author, the presence of behavioral loyalty, in the absence of attitudinal loyalty is often characterized as spurious loyalty. Such loyalty may be a result of factors like convenience or non-availability of an alternative (Labrecque, L. I., Krishen, A. S., and Grzeskowiak, S., 2011), and customers may switch to an alternative when such an option becomes available. "On the other hand, the presence of attitudinal loyalty, in the absence of behavioral loyalty is often referred to as latent loyalty. This situation is one where the customer may hold the brand in high esteem, or may have an emotional attachment with the brand, but does not purchase the brand. Therefore, one notes that the presence of both types of loyalty is necessary for true loyalty to exist (Labrecque, L. I., Krishen, A. S., and Grzeskowiak, S., 2011).”

The authors contend that customers periodically seek value in their exchange relationship with brands (e.g., Mostert, P. G., Petzer, D. J., and Weideman, A., 2016). Extant literature supports that greater perceived value leads to greater attitudinal and behavioral loyalty (Solomon, M., 2016). Finally, according to the author, "research finds that a consumer's prior disposition is an important moderator of advertising response (Von Freymann, J. W., 2006). If the consumer is a loyal user of the brand or is familiar with it, the positive response to exposure is likely to be higher. Research also suggests that advertising is more effective in increasing the volume purchased by loyal buyers but less effective in winning new buyers (Solomon, M., 2016). Based on Smith K. (2016) research, findings established how organizations can target the millennial generation, "one of the most commanding publics in terms of purchasing power and influence" with social media. It is important to understand the fact that millennials have been surrounded with technology for so long that they cannot imagine their lives without digital media. Organizations can use social media as a "strategic marketing tool for companies to promote, solicit donations, support causes, and interact with publics. Utilizing social media not only provides another medium to communicate, but also it delivers messages in a way that encourages engagement resulting in relationship development" (Barber, N., Dodd, T., and Ghiselli, R., 
2008). Doster (2013) contends it is important to gain an understanding of the millennial subculture and their self-presentation and communication styles as they have a significance on the implications when applying marketing strategies today and in the future.

Given that generation $\mathrm{Y}$ is the largest demographic in the United States at a staggering 94 million, (Census, 2010) along with constant exposure to media, product, and lifestyle choices, the millennials requires a unique marketing approaches that far differ from those of previous generations. Consumers display different sets of decision making styles guiding their purchase decisions. Eastman (2013) remarks that status consumption is an attempt by the consumer to improve their social standing through purchasing certain products that align with a specific image. The consumer wants to portray that the conspicuous consumption of consumer products that confer and symbolize status both for the individual and surrounding significant others". Marketers can better meet the needs of their millennial shoppers by determining if status consumption is impacting millennials' shopping styles. Over the years there has been a shift in shopping styles from what it used to be with previous generations and currently with millennials. Stocchi, L., Driesener, C., and Nenycz-Thiel, M., 2015) argue that prestigious brand-name clothing is very important to adolescents". In a 2002 study of young status conscious consumers found they are more likely to be affected by a status brand's symbolic characteristics, by feelings evoked by the brand and by the degree of congruence between the brand-user's self-image and the brand image. Reisenwitz, T., and Gupta S. (2016) suggest that younger consumers spend more on branded products including status products. Finally, Barber, N., Dodd, T., and Ghiselli, R., 2008) found that millennials are the cohort most likely to buy prestigious clothing, while Boomers are significantly less-prestige sensitive. Thus, the literature suggests that branding is a key element of status products, particularly for younger consumers (Barber, N., Dodd, T., and Ghiselli, R., 2008). Finally, millennials are very success-driven (Howe, N., and Strauss, W., 2000) and status products may be one way they can demonstrate their success." The millennial consumers who are motivated to consume for status, will utilize the shopping styles of being brand conscious and brand loyal (Eastman, 2013). Scientific research has been conducted to understand how and where exactly these brands are positioned in the human brain. Because of new techniques in neuroscience, there is much potential to overcome the limits of self-report measures by which consumers are unable or unwilling to fully articulate their thoughts and preferences. The utilization of neuroscientific techniques to marketing strategies has a brief existence but has been a controversy (Garvey, A.M., Germann, F., and Bolton, L. E., 2016). Bucic et al., (2012) argued that millennials should be treated as an assortment of submarkets that vary in stages of awareness to ethical issues, consider distinct motivations when making purchase decisions, and are willing to engage in cause-related purchasing to varying degrees. This implies that millennials will feel more passionate about purchase decision if it is backed by a specific cause. However, on the contrary, ethical consumerism is based on social, "nontraditional components of products (Doster, L., 2013) and personal and moral beliefs."

In the service settings, Doster, L. (2013, p.16) observes that "the psychological disposition of females indicates that they may be more brand loyal." (Keller, K. L., 2009) found that men are less brand loyal compared to women in the grocery product market. To build off of this theory, (Liu-Thompkins, 2013, Y., and Tam, L.,2013) found that achieving brand loyalty is different between genders depending upon product type, whether utilitarian or hedonic. However, they found that in both studies, women are more strongly influenced toward loyalty behaviors. Putre, L. (2013) also found that mature age groups (35-54 and over 55 years of age) showed significantly more loyalty than younger age groups (18-24 and 25-34 years of age). This may be because older consumers evaluate their experience with the product at the time of the purchase decision (Russell, B., 2015). It is also worth noting that this research supports other theories in the case of consumers within lower income thresholds displaying lower levels of brand loyalty. Based on the author's analysis, younger customers who purchase the warranty were more brand loyal than older customers. This significant result, although in the opposite direction of the author's hypothesis, concurs with more recent surveys where the relationship between brand loyalty and age has been overstated and where brand loyalty varies more by category than by age (Smith K., 2016). Additionally, customers with higher incomes were significantly more store loyal than customers with lower incomes. The results suggest that an eyeglass warranty at a retail optical center is important for younger customers in terms of brand loyalty and higher income customers in terms of store loyalty (Reisenwitz T, 2016).

Per research, marketers should have knowledgeable of three degrees of brand loyalty that can be identified: brand recognition, brand preference and brand insistence (Van der Lans, R., Pieters, R., and Wedel, M., 2008). Brand Recognition is of lesser brand loyalty (Solomon, M., 2016). This occurs when consumers know of a specific brand and would consider purchasing from that particular brand (Russell, B., 2015). The brand would serve as a potential alternative when the consumer's preferred brand is unreachable (Lotfizadeh, F., and Lotfizadeh, F., 2015). Because of this, businesses attempt to create brand recognition in hopes of creating brand preference. Brand preference occurs 
when a specific brand is favored over competing brands (Keller, K. L., 2009). However, despite showing signs of brand preference, customers accept an alternative brand when their preferred brand is unavailable. Rather than exerting additional effort locating a replacement brand, these types of consumers will find and purchase their preferred brand (Lambert-Pandraud, R., and Laurent, G., 2010). Brand insistence is considered to be the strongest form of brand loyalty. Customers will remain absolutely loyal to their favored brands and will not accept any alternatives. Instead they will desperately attempt to find and purchase their favored brand. If their preferred brand is unobtainable, the consumer will even go as far as suspending the purchase altogether if necessary. (Kaplan Thaler, L., \& R. Koval., 2003) Lastly, the author uses studies from Bresler that argues Millennial's brand loyalty is a determinant of how well the brand satisfies their needs. Regarding Generation Y, a number of studies (Kaplan Thaler, L., and R. Koval., 2003: Doster, L., 2013: Balaji K. V., V., \& Indradevi, R., 2015) established that millennial buyers' satisfaction predict their loyalty.

Von Freymann (2006) contends that generational demographics such as age can determine how a customer perceives a grocery store's services, quality and attitude. Researchers have argued that a consumer's age and generational class may affect purchase choices (Putre, 2013). In cases of an actual purchase choice, such as at what store will they purchase their groceries each week, consumers will choose either directly based on their attitudes and feel of the prime attributes or central merits of the object according to the author (Von Freymann, J. W., 2006). Consumers typically represent themselves as one of seven different shopper types; namely, price, convenience, quality, value, service, store, or combination shopper (Von Freymann, 2002). Additionally, in ongoing store choice, these three major components (location, price, and services) combine to affect consumer decision-making for each succeeding visit. Attitude is an integral element in exactly how customers view a brand's services or products. "Attitude is comprised of three parts: the cognitive, the affective, and the behavioral. As a component of the buyer behavior process, attitude brings together a consumer's internal evaluation of a brand, affecting purchase intent and purchase choice (Howe and Strauss, 2000)." It is a learned predisposition to respond ... [for] the way we think, feel, and act toward some aspect of our environment such as a retail store, television program or product" (Howe and Strauss, 2000). Emotion is part of the affective system in attitude; and as such, an integral part of the buyer behavior process.

The author argues that emotion may come from a conscious response to an event or thought and be physiologically connected and physically expressed, with specific responses to the emotion (Balaji K. V., V., and Indradevi, R.,2015). "More specifically, consumptive emotions can be separated into positive or negative experiences, such as the general joy of a shopping trip or the specific sadness or frustration of not finding certain wanted attributes in a favored brand. Each on its own and together can affect the brand choice (Liu-Thompkins, 2013, Y., and Tam, L., 2013).” According to Russel, fifteen separates general or specific consumptive emotional outcomes are listed by Russel.B., (2015) with the positives as joy, hope, relief, pride, liking, and surprise; and the negatives as fear, sadness, distress, frustration, dislike, anger, shame, guilt, and regret. Results of the study indicated that the authors' hypothesis and argument was correct. Regression analysis indicated that a significant relationship does appear to exist between shoppers' ages and perceived grocery store services quality attitude assessments (Von Freymann, J. W. 2006). Furthermore, according to the author, a one-way ANOVA analysis indicated that there is a significant difference between grocery store shoppers' generational cohorts in relation to the grocery store services quality assessments. Of the 28 individual perception items, six items show significance at $\mathrm{p}<0.05$ with generation $\mathrm{Y}$, individual customer attention, customer courtesy, and high-quality merchandise available. This indicates that based on this study, millennials will either have a positive or negative attitude towards a brand heavily based on those six variables (Von Freymann, J. W. 2006).

Particularly, brand experience has indeed attracted a lot of attention in marketing practice. Marketing practitioners have come to realize that understanding how consumers experience brands is critical for developing marketing strategies for goods and services (Brakus, 2009). This author argues that the concept of how a customer experiences a brand needs to be thoroughly analyzed, as the experience a customer has with a brand can affect loyalty (Brakus, 2009). Ultimately, when experiences occur they affect judgments, attitudes, and other aspects of consumer behavior. Because of the vitality of this concept the author has developed a brand experience scale. The author argues that "most of the research on experiences to date has focused on utilitarian product attributes and category experiences, not on experiences provided by brands. When consumers search for, shop for, and consume brands, they are exposed to utilitarian product attributes (Brakus, 2009). However, they are also exposed to various specific brand-related stimuli, such as brand-identifying colors (Balaji K. V., V., and Indradevi, R., 2015), shapes (Van der Lans, R., Pieters, R., and Wedel, M., 2008), typefaces, background design elements (Maity, M., and Gupta, S., 2016), slogans, mascots, and brand characters (Keller, 1998). These brand-related stimuli appear as part of a brand's design and identity (e.g., name, logo, signage), packaging, and marketing communications (e.g., advertisements, brochures, Web sites) and in environments in which the brand is marketed or sold (e.g., stores, events). These brand-related stimuli 
constitute the major source of subjective, internal consumer responses, which we refer to as "brand experience" (Brakus, 2009). According to the author brand experiences vary in strength and intensity; that is, some brand experiences are stronger or more intense than others (Brakus, 2009). If a brand evokes an experience, this alone may lead to satisfaction and loyalty. In addition, an experience may be the basis for more elaborative information processing and inference making that result in brand-related associations (Keller 1993). In turn, these associations may affect satisfaction and loyalty. Because experiences provide value, the author expects that the more a brand evokes "multiple experience dimensions", the more satisfied a consumer will be with the brand (Brakus, 2009). In addition, the author contends, "because experiences result from simulations and lead to pleasurable outcomes, consumers will want to repeat these experiences" (Brakus, 2009). If this is the case "brand experiences directly impact the loyalty consumers devote to brands". Lastly, it has been proven that consumer satisfaction impacts brand loyalty. "When a consumer feels good about the relationship and appreciates the product or brand, a high level of commitment and loyalty results (Eastman, J. K., Iyer, R., and Thomas, S. P., 2013)." This assumption is valid and reliable as multiple sources and references indicate this exact detail throughout this literature survey.

The authors' findings were positive as the author's core argument was supported. Based on the tests, brand experience and brand personality exhibited high levels of discriminant validity (Brakus, 2009). Furthermore, the author state "experience affects satisfaction and loyalty both directly and indirectly through brand personality (Brakus, 2009). The direct and indirect effects of brand experience on loyalty are roughly equal. Furthermore, the author states, "experience affects satisfaction and loyalty both directly and indirectly through brand personality (Brakus, 2009). However, the author states that the effect from brand experience have differential effects. He states that brand experiences have a direct effect on brand loyalty is higher than its direct impact on satisfaction (Brakus, 2009). The author also states that marketers should engage in projects to understand and improve the experience their brands provide for their customers, they can use the scale for assessment, planning, and tracking purposes (Brakus, 2009).

Liu-Thompkins argues that customers who repeat purchases at a single location are not necessarily brand loyal based his study that will be later touched on. "In a comprehensive discussion of brand loyalty, Kellison et al., (2013, p. 34) defines loyalty as "a deeply held commitment to rebuy or re-patronize a preferred product/service consistently in the future, thereby causing repetitive same-brand or same brand-set purchasing, despite situational influences and marketing efforts having the potential to cause switching behavior." The author goes on to argue that there are two types of brand loyalty, attitudinal and habit (Liu-Thompkins, 2013). Attitudinal loyalty is defined as a strong intention to buy from the brand and eventually repeat purchase behavior (Reisenwitz T, Gupta S., 2016). Habitual loyalty is defined by the author and Dick and Bucic (2012) as "spurious loyalty", which is essential fake loyalty. Additionally, the author argues that habitual loyalty is behavioral loyalty which again is viewed by the author as ingenuine. Furthermore, the author argues that attitudinal loyalty and habit can result in similar purchase behavior. Both lead to persistent choice of the same brand, despite unfavorable factors such as a higher price (Howe, N., and Strauss, W., 2000). When competing brands try to influence customer switching (brand switching), both attitudinally loyal and habitual customers may be exceedingly unaffected to such efforts (Doster, L., 2013). But, the author contends that despite these similarities, attitudinal loyalty and habitual loyalty "operate at different levels. Attitudinal loyal customers are motivated by satisfactory attitudes and perceptions. While habitual loyalty is dependent on the type of scenario. (Liu-Thompkins, 2013). Simply meaning that customers who display attitudinal loyalty whole heartedly believe and actually like the brand. Because of these customers are not inclined to switch even at a lower price point from competitors, while habitual loyalty is fostered because the price of the good resonates well with the consumer. Meaning that if a similar brand sells similar goods and services at a lower price point the consumer will be inclined to switch.

Researchers have attributed the development of attitudinal loyalty to a variety of factors, one being satisfaction (Kakati, R. P., and Choudhury, S., 2013) and perceived value (Kapferer, J.-N., 2005). However contrarily, the only crucial aspects for habitual loyalty are dependent of repetition and stable context (DeVaney, S. A., 2015). Habit is developed through repetition in a consistent context (Labrecque, L. I., Krishen, A. S., and Grzeskowiak, S., 2011). Whereas attitudinal loyalty builds on conscious brand evaluation, consumers may be unaware of the associative learning process that leads to habit" (Liu-Thompkins, 2013). Through his research and based on his study he found that "attitudinal loyalty increased the effectiveness of a cross-selling promotion, whereas habit showed the opposite effect and rendered the same promotion less effective" (Liu-Thompkins, 2013). IN other words, customers who were attitudinal loyal were easier to cross sell compared to habitual loyal customers. Interestingly enough the author also states a "generic cross-selling promotion not only is ineffective in moving habitual consumers to the new category but can also negatively affect their purchases in the old category, even after the promotion ends". This indicates that 
habitual loyal customers need strategic targeting strategies implemented to cross-sell them instead of general techniques as it could negatively impact spending in the long run (Liu-Thompkins, 2013).

According to Barber, Dodd and Ghiselli (2008) market segmentation and consumer traits, such as "product knowledge, purchase confidence, and generational differences can impact purchase decisions. One example of this in the wine industry. When segmenting consumers into generational classes, it can become clearer to identify that specific classes' preferences and in turn help better develop recommendations concerning generational-based segmentation advertising and marketing strategies. Studies indicate that there are differences in how the younger generation's view marketing tactics. For example, Generation $\mathrm{X}$ would require "to the point advertisements that create a product image closest to this group's views, while Millennial would require images of friends and shareable moments (Barber, N., Dodd, T., and Ghiselli, R. 2008).

According to Lam (2010) findings using social identity theory and brand loyalty literature, it was possible to examine issues such as specific market disruptions such as the "introduction of a radically new brand". The framework focuses on customer's identification with the new brand along with their switching behavior. "People derive their identity from their affiliations with social groups. They value such membership and distinguish themselves from those who did not share such affiliations, forming the in-group and the out-group. When a social identity is threatened, in-group members will likely respond by resorting to three basic strategies: social mobility, social creativity, and social change." As a result, "social change can be initiated either by competitors or by customers who identify with a brand. Market disruptions that are externally caused by competitors can be viewed as attempts to initiate social change between competitors to vie for customers' favor. When a radically new brand is introduced, some customers may perceive the new brand as having a more attractive identity than the incumbent's identity. From a customer's perspective, brand identifiers sometimes proactively generate negative word of mouth about brands that they do not identify with, especially after they are exposed to comparative advertising." Building on social identity theory (Saddlemyer, J., and Bruyneel, S., 2016) and the customer-company identification framework to formally propose the concept of customer-brand identification (CBI). Lam (2010) defines CBI as a customer's psychological state of perceiving, feeling, and valuing his or her belongingness with a brand. According to Lam (2010), "customers may switch to a new brand for self-enhancement purposes to maximize socio psychological utility rather than functional utility."

\subsection{Brand Resonance}

According to studies of Kevin Lane Keller (2009), the brand resonance pyramid is considered an important tool for marketers to implement marketing communications that can "create intense, active loyalty relationships and affect brand equity". A study conducted by Kevin Lane Keller in 2009 established how integrating marketing communications involves "mixing and matching different communication options to establish the desired awareness and image in the minds of consumers". This will become significant for brand managers when positioning brands in the minds of consumers, especially millennials who will be the target audience of the future. The author argues that due to new technology and internet, brand marketers face challenges as to how they build and manage their brands. The study examines the ways in which the "marketing communications has changed". "Traditional advertising media such as TV, radio, magazines and newspapers are losing their grip on consumers. Technology and other factors have profoundly changed when, where and how consumers process communications, and even whether they choose to process them at all. The rapid diffusion of powerful broadband Internet connections, ad-skipping digital video recorders, multi-purpose cell phones and portable music and video players have forced marketers to rethink many of their traditional practices (Kaplan Thaler and Koval, 2003; Kellison, T. B., Yu Kyoum, K., and Magnusen, M. J.,2013). This study also provides insights as to how marketers can take a "broader perspective in their marketing communication strategies when building brand equity". To create brand resonance, marketers must first create a foundation on which resonance can be built. According to customer-based brand equity model, resonance is most likely to result when marketers are first able to create; proper salience and breadth and depth of awareness; firmly established points-of-parity and points-of-difference; positive judgments and feelings that appeal to the head and the heart. Brand resonance pyramid model (see figure 1) is encapsulated with the following elements such as, Brand Salience: difficulty and frequency of which customers have a brand in their thoughts when making a purchase or consuming product/service, Brand Performance: is the way in which the product/service meets customers' functional needs, Brand Imagery: ability to describes the acquired properties of the product/service, including the ways in which the brand attempts to meet customers' psychological or social needs, Brand Judgments: customers' personal opinions and evaluations, Brand Feelings: customers' emotional responses and reactions with respect to the brand, and Brand Resonance: relationship customer have with the brand and the extent to which "they feel they are in sync with the brand." 


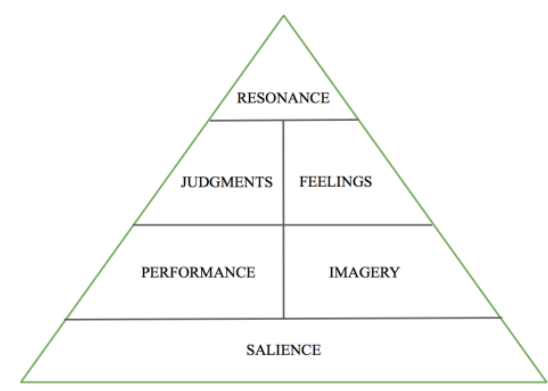

Figure 1. Brand Resonance pyramid customer-based brand equity model pyramid

Source: Keller, K. L. (2009). Building strong brands in a modern marketing communications environment. Journal of Marketing Communications, 15(2/3), 139-155.doi:10.1080/135272609 02757530

\section{Hypotheses}

Based on the above factors, the following theoretical framework (see Figure 2) and hypotheses are proposed:

\subsection{Millennials and Brand Loyalty}

Lam, S. K., Ahearne, M., Hu, Y., and Schillewaert, N. (2010) argues that people derive their identity from their affiliations with social groups. They value such membership and distinguish themselves from those who did not share such affiliations, forming the in-group and the out-group. When a social identity is threatened, in-group members will likely respond by resorting to three basic strategies: social mobility, social creativity, and social change. Consumer seeks many sources to add value to their self-image. The association with certain brands will help to achieve the objective. Customer-Brand Identification (CBI) as a customer's psychological state of perceiving, feeling, and valuing his or her belongingness with a brand. Customers may switch to a new brand for self-enhancement purposes to maximize socio psychological utility rather than functional utility (Lam, S. K., Ahearne, M., Hu, Y., and Schillewaert, N., 2010). Millennials are more likely to be affected by a status brand's symbolic characteristics, by feelings evoked by the brand and by the degree of congruence between the brand-user's self-image and the brand image (Eastman and Liu 2013). Doster (2013) suggests that younger consumers spend more on branded products including status products. When status-seeking consumers discover which brands convey status that they will stay with those brands for as long as the status effect lasts (Liu-Thompkins, Y., and Tam, L., 2013). Millennials are more likely to be affected by a status brand's symbolic characteristics, by feelings evoked by the brand and by the degree of congruence between the brand-user's self-image and the brand image. Doster (2013) suggests that younger consumers spend more on branded products including status products. Finally, Mostert, P. G., Petzer, D. J., and Weideman, A. (2016) found that millennials are the cohort most likely to buy prestigious clothing, while Boomers are significantly less prestige sensitive. Depending on generational demographic, how a consumer views perceived store services quality and attitude is based on age. As such, age plays a vital role in determining the degree of the service quality. Van der Lans, R., Pieters, R., and Wedel, M. (2008) contend that they are not opportunistic in their dealings with the brand, are less price-sensitive, have a long-term relationship perspective, and could ultimately be more profitably served. Furthermore, Kumar suggests that customers' relationship intentions comprise five sub-constructs: involvement, expectations, forgiveness, feedback and fear of loss of the relationship. Maity, M., and Gupta, S., (2016) argue that customers who are not members of loyalty programs are less affected by advertisements and these advertisements do not significantly affect attitudinal or behavioral loyalty (Maity, M., \& Gupta, S., 2016). Customers who are members of LP's (loyalty programs) are more effectively impacted by attitudinal loyalty through advertisements (Maity, M., \& Gupta, S., 2016). Based on this empirical evidence, we propose the following:

Hypothesis 1: Millennial respondents will have lower Brand Loyalty scores than Gen X/Baby Boomer respondents.

\subsection{Brand Resonance, Brand Loyalty, and Generation}

In the business and marketing world, brand image has been defined by Keller (1993) as the set of information consumers associate with a brand in their memory, commonly referred to as brand image associations. Early research on brand image data (Barber, N., Dodd, T., and Ghiselli, R., 2008) demonstrated the existence of 'a simple and systematic pattern' binding brand image and brand usage. Through this study, it was found that there is a positive 
correlation between brand image and brand usage. A study by Garvey, A.M., Germann, F., and Bolton, L. E. (2016) and Kakati, R. P., and Choudhury, S. (2013) gave the idea and conceptualization that smaller brands do not report the usage numbers that larger brands do due to the fact that smaller brands have less brand images than the larger brands do. Brand imagery deals with the extrinsic properties of the product or service including the ways, in which the brand attempts to meet customers' psychological or social needs. Brand imagery is how people think about the brand abstractly rather than what they think the brand actually does (Kakati and Choudhury 2013). Kakati and Choudhury (2013) ran a study for brand imagery with five different fields of the area to determine the most looked upon qualities. These qualities include convenience to purchase, attractive purchase, good warranty, easy instalment, good slogan, and good packaging. These are all qualities that Millennials look for in the products they buy. Keller (1998) defined brand salience as the ability of customers to identify brands. Although it is known that using one's logo or stamp on a product is the norm throughout the marketing world, Justin Saddlemyer and Bruyneel (2016) argue in their study that more high- end quality brands may shrink down and blend in their brand's logo. Justin Saddlemyer and Bruyneel (2016) defend that brands may be able to do this to let the product speak for itself in terms of quality and performance. Brands often use a variety of marketing signals to represent quality, at varying costs. (Saddlemyer, and Bruyneel, 2016) For example, a firm may offer a product warranty, which may incur costs to the brand at a later point in time but is viable for firms with high quality (Labrecque, L. I., Krishen, A. S., and Grzeskowiak, S.,2011). Things such as warranties can be a subliminal message to people that the brand has a warranty due to the low quality of a brand. Despite the given information of a product during the time of the purchase or search, Kellison, T. B., Yu Kyoum, K., and Magnusen, M. J. (2013) offer the idea that customers may respond to different brands differently based on their knowledge about the brand, therefore, creating a brand that is known is the main focus of salience, and but along with the studies done by Saddlemyer and Bruyneel (2016), one can conclude various ways a brand may be able to do so. This expectation is formally captured in the following hypothesis;

Hypothesis 2: Brand Resonance scores will be positively correlated with Brand Loyalty scores, and Generation will moderate the strength of the relationship. We expect the correlation will be lower for Millennials than for Gen $\mathrm{X} /$ Baby Boomers.

\subsection{Brand Resonance Pyramid}

When it comes to the performance of a product/brand, Millennials are known to want the latest and greatest. According to Keller (2009), brand performance refers to the intrinsic properties of the brand in terms of inherent product or service characteristics which define the functional performance of the product as expected by all customers. Brand Performance can be an objective field because the performance of a product is based off two set of eyes, the users and the brands. The performance image is taken from what the brand portrays the performance as, and how the consumer views it as, but the performance can shift between customers on the same product based on initial thoughts and expectations of a product. Belonging is one of five core social motives, the midpoint in Maslow's hierarchy of needs (Smith K., 2016), and essential for group survival. Despite the need to belong, consumers may be motivated to break away from concerns over what others may think of them, how others may act toward them as a function of their product choices, or a number of other social situations (Labrecque, L. I., Krishen, A. S., and Grzeskowiak, S., 2011). When it comes to a product performance, it is a factor taken into play, and the performance of a product as seen in the consumer's eyes may outweigh the performance of a product as viewed in the eyes of other consumers/peers and the company. In the modern world, becoming brand conscious and making positive choices among adolescent is increasing (Russell, B., 2015). Many consumers are selecting their brand preferences between the ages of 15 and 25 (Smilansky, O., 2016). Furthermore, among young consumers, peers and the like are playing a vital role in the marketplace, this is because they make heavy influences by their purchases and choices of brands (Stocchi, L., Driesener, C., and Nenycz-Thiel, M., 2015). Another argument established by Raut (2015) is that purchase intention is stronger when consumers' age is lower, and education is higher (Raut, U. R., 2015). Millennial consumers who are motivated to consume for status will utilize the shopping styles of being brand conscious, novelty/fashion conscious, recreational shoppers, impulsive shoppers, and brand loyal (Eastman, J. K., Iyer, R., and Thomas, S. P., 2013). Brand Recognition: the mildest form of brand loyalty (Yu-Ping, C., Nelson, L. D., and Ming, H., 2015), occurs when customers know about a specific brand and would consider it when making a purchase (Von Freymann, J. W., 2006). Customers who are members of LP's (loyalty programs) are more effectively impacted by attitudinal loyalty through advertisements (Maity, M., and Gupta, S., 2016). It is important to understand the fact that millennials have been surrounded with technology for so long that they cannot imagine their lives without digital media. Organizations can use social media as a "strategic marketing tool for companies to promote, solicit donations, support causes, and interact with publics. Utilizing social media not only provides another 
medium to communicate, but also it delivers messages in a way that encourages engagement resulting in relationship development" (Barber, N., Dodd, T., and Ghiselli, R. 2008). Thus, we propose the following;

Hypothesis 3: We expect our data to reflect the structure of the Brand Resonance pyramid as described by Keller (2009).

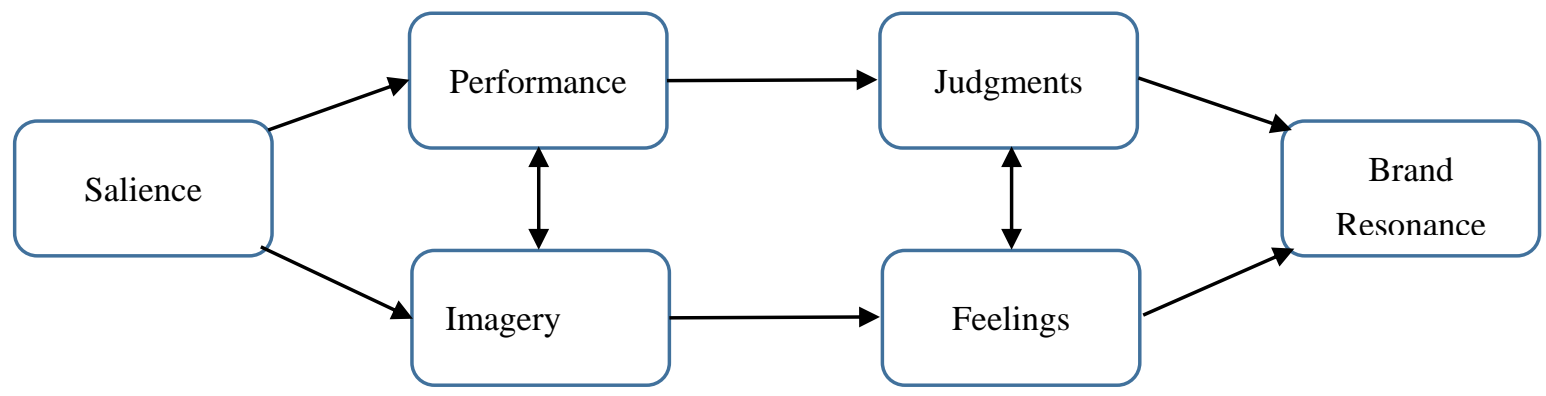

Figure 2. Structure of the Brand Resonance pyramid (hypothesis 3)

\section{Methodology}

We conducted our investigation based on any brand the respondents could think of given in a five-year reflection window period to understand the degree of the moderation of each dimension that influence brand resonance based on Kevin Lane Keller's work (Brand Resonance Pyramid) established. Strength of elements indicated in the brand resonance pyramid is tested using hierarchical regression. Finally, based on the statistical analysis, brand management strategies are proposed to target millennials specifically in building brand resonance.

\subsection{Measures}

\subsubsection{Generation}

The age groups in the survey were 18-24, 25-34, 35-40, and 41 or older. These most closely aligned with the generation definitions of the Strauss-Howe generational theory. According to Howe and Strauss (2000), the Millennial cohort consists of U.S. children born from 1982 to 2002 . The two generations prior to 1982 were Generation X from 1961 to 1981 and Baby Boomers from 1943 to 1960. The four levels of the Age Group variable were recoded to form two Generation variables, one with two levels and the other with three. In the two-level variable, "Millennial" consisted of the 18-24 and 25-34 age groups; 35-40 and 41 or older were coded as "Gen X or Boomer." For the three-level variable, Gen X or Boomer was defined in the same way, but 18-24 and 25-34 were coded respectively as "Younger Millennial" and "Older Millennial."

\subsubsection{Brand Loyalty}

Respondents were asked to rate their loyalty to a brand they purchased and used over the past five years using a 5-point Likert scale from Very Low, Low, Moderate, High, and Very High. Eight aspects of Brand Loyalty were assessed, including Awareness, Recall, Relate, Purchases, Knowledge, Trials, Associations, and Recommendations. These aspects were based on the work of Kevin Lane Keller (2009).

\subsubsection{Brand Resonance}

Following the Brand Loyalty questions, respondents were asked to answer questions based on concepts described in Keller's brand resonance pyramid (2009). According to Keller, marketing communications build strong brands by influencing customers' awareness and perceptions of the brand. The pyramid describes two conceptual pathways, one rational and one emotional, that establish the nature of the customer's relationship with the brand. The foundation of the pyramid is the salience of the brand, the ease with which it comes to the consumer's mind. The emotional pathway progresses through the imagery that the brand evokes in and the consumer's emotional responses. The rational pathway considers how well the brand performs and consumers' opinions about the brand. In the survey, respondents were asked to consider the six elements of brand resonance in relation to the same brand they were thinking of in the previous section. On a 5-point Likert scale from Very Low to Very High, respondents rated these elements using multiple survey items: Salience (4 items), Imagery (4 items), Performance (8 items), Feelings (6 items), Judgment (8 items), and Resonance (5 items). 


\subsection{Sample Description}

Authors used a simple random sampling procedure to respond to the online survey administered using SurveyMonkey. The sample frame includes college students, faculty, and staff. The survey was administered internationally based on regions (Easters Africa, Middle Africa, North Africa, South Africa, Latin America and Caribbean, Middle East, North America, Central America, etc.). A total of 267 individuals responded to the survey. However, 87 of them (32.6\%) did not provide sufficient data to be included in the analysis. Of the remaining 180 , 119 provided valid data for the questions related to both Brand Loyalty and Brand Resonance. The sample size for the analysis of Hypothesis 1, the relation between Generation and Brand Loyalty was 180, but the sample size for Hypotheses 2 and 3 was 119. Table 1 provides absolute and relative frequencies for 5 covariates in the statistical models: Generation, Residential Status, Education, Income, and Employment Status.

Table 1. Respondent Characteristics

\begin{tabular}{llll} 
Variable & Category & Count & Percent \\
\hline Sample Size & & 180 & $100 \%$ \\
\hline Generation & Millennial (18-34 years) & 144 & $80.0 \%$ \\
& $\quad$ Younger Millennial (18-24) & & 118 \\
& $\quad$ Older Millennial (25-34) & 26 & $65.6 \%$ \\
& Gen X or Boomer (35+ years) & 36 & $14.4 \%$ \\
\hline Residential Status & United States & 161 & $80.0 \%$ \\
\hline Education & Outside the United States & 16 & $89.4 \%$ \\
& Unknown & 3 & $1.7 \%$ \\
\hline Income & Less than a college degree & 97 & $53.9 \%$ \\
& College degree or greater & 82 & $45.6 \%$ \\
& Unknown & 1 & $0.6 \%$ \\
\hline \$20K or less per year & 98 & $54.4 \%$ \\
& \$21K to \$50K per year & 49 & $27.2 \%$ \\
& Over \$50K per year & 31 & $17.2 \%$ \\
& Unknown & 2 & $1.1 \%$ \\
\hline Employment Status & Student & 84 & $46.7 \%$ \\
& Employed full-time & 70 & $38.9 \%$ \\
& Other & 26 & $14.4 \%$ \\
\hline
\end{tabular}

Chi-square tests were conducted to assess whether respondents with complete data differed from respondents with missing Brand Resonance data in terms of Generation, Residential Status, Education, Income, or Employment Status. None of the tests were statistically significant, indicating that the group with missing data was similar to the group with complete data, at least in terms of these four variables.

\subsection{Scale Reliabilities}

Scale reliabilities for Brand Loyalty and the six elements of the brand resonance pyramid were assessed using Cronbach's alpha and are reported in Table 2. 
Table 2. Descriptive statistics and scale reliabilities for Brand Loyalty and Brand Resonance scales

\begin{tabular}{|c|c|c|c|c|c|}
\hline Scale & $\begin{array}{l}\text { Number of } \\
\text { Items }\end{array}$ & $\begin{array}{l}\text { Cronbach's } \\
\text { Alpha }\end{array}$ & Sample Size & Mean & SD \\
\hline Brand Loyalty & 8 & .887 & 172 & 2.44 & 1.09 \\
\hline Salience & 4 & .845 & 120 & 2.61 & 1.05 \\
\hline Imagery & 4 & .864 & 121 & 2.49 & 1.14 \\
\hline Performance & 8 & .904 & 117 & 2.81 & 0.92 \\
\hline Feelings & 6 & .904 & 119 & 2.47 & 1.22 \\
\hline Judgment & 8 & .932 & 118 & 2.56 & 0.99 \\
\hline Resonance & 5 & .901 & 115 & 2.33 & 1.35 \\
\hline
\end{tabular}

All scales were highly reliable with alphas of .845 and higher, so mean scores were computed for Brand Loyalty, Brand Resonance, and the other five elements of Brand Resonance.

\section{Results}

\subsection{Relation of Generation to Brand Loyalty}

A general linear model was constructed to measure the predictive relationship between Brand Loyalty scores and Generation, controlling for Residential Status, Education, Income, and Employment Status. The model accounted for just $4.7 \%$ of the total variance in Brand Loyalty scores and Generation was not a significant predictor. The least squares mean for Millennials was 2.41, 95\% CI [2.12, 2.71], and 2.63, 95\% CI [2.32, 2.93] for Gen X/Boomers. None of the other covariates in the model were statistically significant. Parameter estimates for the model are presented in Table 3. A follow-up analysis included a 3-level variable for Generation, separating out younger Millennials from older. While the difference between younger Millennials and Gen X/Boomers was stronger than for older Millennials, none of the pairwise comparisons were statistically significant.

Table 3. Parameter estimates for Brand Loyalty prediction model I

\begin{tabular}{lllllll}
\hline & \multicolumn{3}{c}{ Std. } & & \multicolumn{3}{c}{ 95\% Confidence Interval } \\
Parameter Estimates & $\mathbf{B}$ & Error & $\mathbf{t}$ & Sig. & Lower & Upper \\
\hline Intercept & 2.79 & .31 & 9.13 & .000 & 2.19 & 3.40 \\
Generation & -.21 & .20 & -1.06 & .293 & -.61 & .18 \\
Residential Status & -.11 & .22 & .51 & .608 & -.54 & .32 \\
Education & .12 & .15 & -.80 & .426 & -.18 & .42 \\
Income (\$20K or less) & -.14 & .23 & -.61 & .545 & -.60 & .32 \\
Income (\$21K to \$50K) & -.01 & .21 & -.06 & .951 & -.43 & .40 \\
Employment Status (Student) & -.16 & .19 & -.82 & .416 & -.54 & .23 \\
Employment Status (Employed Full-Time) & -.17 & .21 & -.84 & .401 & -.58 & .24
\end{tabular}

Note. The Intercept refers to the predicted Brand Loyalty score for the reference group (Gen X/Boomers from outside the U.S. with at least a college degree, making over $\$ 50 \mathrm{~K}$ per year and an employment status classification of Other).

\subsection{Relation of Brand Resonance to Brand Loyalty and Moderation by Generation}

We constructed a second general linear model to measure the predictive relationship between scores on Brand Loyalty and Brand Resonance. Generation was included in the model to assess moderation effects, i.e., an interaction 
between Brand Resonance and Generation. The non-significant covariates from the first model were dropped from the second model. Effect tests for the model are presented in Table 4. The second model accounted for $43.0 \%$ of the variance in Brand Loyalty, a substantial improvement over the first model. An overall effect for Brand Resonance was found; however, Generation moderated the strength of the effect.

Table 4. Test of effects for Brand Loyalty prediction model II

\begin{tabular}{llllll}
\hline Source of Effect & Sum of Squares & $\mathbf{d f}$ & \multicolumn{2}{l}{ Mean SquareF } & Sig. \\
\hline Intercept & 490.55 & 1 & 490.55 & 1258.91 & .000 \\
Generation & 0.04 & 1 & 0.04 & 0.11 & .741 \\
Brand Resonance & 33.23 & 1 & 33.23 & 85.28 & .000 \\
Brand Resonance * Generation & 2.96 & 1 & 2.96 & 7.59 & .007 \\
Error & 44.81 & 115 & 0.39 & &
\end{tabular}

Note. $\mathrm{R}$ Squared $=.430$

As shown in Figure 3 below, the Brand Resonance effect for both groups was positive, but the effect was weaker for Millennials than Gen X/Boomers. For Millennials, a one-unit increase in Brand Resonance was associated with a 0.42 increase in Brand Loyalty, 95\% CI [0.28, 0.56]. For Gen X/Boomers, the slope was much steeper at 0.77, 95\% CI $[0.56,0.99]$.

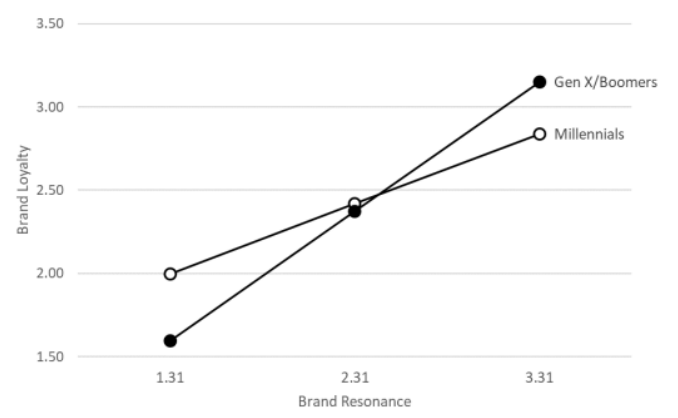

Figure 3. Predicted estimates of the relationship between Brand Resonance and Brand Loyalty by Generation

\section{Discussion}

Using an independent samples $t$-test Hypothesis 1 was tested and found to be not confirmed. There was insufficient evidence to conclude that Millennials have lower Brand Loyalty than Gen X/Boomers. However, Hypothesis 2 was confirmed, we found a strong positive relationship between Brand Resonance and Brand Loyalty and the strength of the relationship was moderated by Generation. As expected, the effect was not as strong for Millennials. The implication of these findings for marketing strategies suggests that Keller's customer-based brand equity model is not fundamentally different for the Millennial generation. As a result, Hypothesis 3 is confirmed. Based on the results of this study findings, we propose the following marketing communication strategies and tactics that could help the academicians, professionals (brand managers, marketing managers, and product managers), and students who pursue education in marketing.

Brand loyalty is defined as "a deeply held commitment to rebuy or re-patronize a preferred product/ service consistently in the future" (Oliver, 1999). It is proven that loyal customers have a higher tendency to purchase products from their preferred brands, are more likely to advocate their favored brands, and are less sensitive to increases in price (Garvey, A. M., Germann, F., and Bolton, L. E.,2016). Demographics, psychographics, and other related sociocultural factors that influence the degree of brand loyalty among the millennials (DeVaney, 2015). Attitude is an integral element in exactly how customers view a brand's services or products (Howe, N., and Strauss, 
W., 2000). Experiences provide value, and the more a brand evokes "multiple experience dimensions", the more satisfied a consumer will be with the brand (Brakus, J. J., Schmitt, B. H., and Zarantonello, L., 2009). Further, because experiences result from simulations and lead to pleasurable outcomes, consumers will want to repeat these experiences (Brakus, J. J., Schmitt, B. H., and Zarantonello, L., 2009). Attitudinal loyalty is defined as a strong intention to buy from the brand and eventually repeat purchase behavior (Mostert, P. G., Petzer, D. J., and Weideman, A., 2016). Attitudinal loyalty increased the effectiveness of a cross-selling promotion, whereas habit showed the opposite effect and rendered the same promotion less effective (Liu-Thompkins, 2013). Based on the above arguments grounded in the body of literature in support of the findings of our study, marketing professional (marketing managers, brand managers, and product managers) should consider the following key factors when designing marketing communication when reaching the Millennials segment specifically; appropriate pricing strategy based on the income parameters (Smith K.,2016), develop a complete and integral marketing programs that develop attitudinal loyalty by providing superior purchasing experiences derives from availability of high-end quality merchandise, utilitarian product attributes, such as brand-identifying colors, typefaces, background design elements, slogans, signages, packaging, advertisements, brochures, websites, and the environments in which the brand is marketed and sold (Yu-Ping,, C., Nelson, L. D., and Ming, H.,2015), crafting generation-based segmentation, advertising, and marketing strategies (Barber, N., Dodd, T., and Ghiselli, R. 2008).

\section{Limitations}

The study suffered high levels of nonresponse. Of the 267 research participants, $32.6 \%$ dropped out during the Brand Loyalty section of the survey, and an additional $22.8 \%$ dropped out while answering the Brand Resonance questions. As a result, only $44.6 \%$ of the total sample completed the survey. No information was collected from participants to explore their reasons for dropping the survey, but there are a handful of reasons that may be relevant. First, participants were asked to think of a brand of their choosing that they had purchased at some point over the past five years. Specific directions about the type of product or service to consider were not given. The lack of specificity and the long reflection window may have weakened their commitment to completing the survey. In addition, the Brand Loyalty and Brand Resonance questions gave very little information about the meaning of the terminology used and how the ratings from Very Low to Very High should be applied. For example, jargon like "test your degree of brand loyalty" were likely difficult to understand for many respondents and it was not always clear how to assign a low to high rating for items like "Relate" or "Associations." Complete sentences and more natural language would have communicated the intent of the questions more effectively.

\section{Future Study}

This study leads a potential future extended work to provide a comprehensive interpretation to the study phenomenon. As such, we intend to carry out our send phase of the study with following modifications incorporated; giving product directions to the respondents by requesting them to provide a specific brand name instead of a common brand to understand their behavior in line with that particular brand, minimizing the reflection window time from five years to two years to recall their brands, finally, providing leman meaning of the technical jargons used in the questionnaire.

\section{References}

Balaji, K. V., V., \& Indradevi, R. (2015). A Study of the Presence of Subclinical Narcissistic Tendencies Among Millennial Generation Adults in A Private University. Global Management Review, 10(1), 1-8

Barber, N., Dodd, T., \& Ghiselli, R. (2008). Capturing the Younger Wine Consumer. Journal of Wine Research, 19(2), 123-141. https://doi.org/10.1080/09571260802622225

Brakus, J. J., Schmitt, B. H., \& Zarantonello, L. (2009). Brand Experience: What Is It? How Is It Measured? Does It Affect Loyalty? Journal of Marketing, 73(3), 52-68. https://doi.org/10.1509/jmkg.73.3.52

Bucic, T., Harris, J., \& Arli, D. (2012). Ethical Consumers Among the Millennials: A Cross-National Study. Journal Of Business Ethics, 110(1), 113-131. https://doi.org/10.1007/s10551-011-1151-z

DeVaney, S. A. (2015). Understanding the Millennial Generation. Journal of Financial Service Professionals, 69(6), 11-14.

Doster, L. (2013). Millennial teens design and redesign themselves in online social networks. Journal of Consumer Behavior, 12(4), 267-279. https://doi.org/10.1002/cb.1407

Eastman, J. K., Iyer, R., \& Thomas, S. P. (2013). The Impact of Status Consumption on Shopping Styles: An Exploratory Look at the Millennial Generation. Marketing Management Journal, 23(1), 57-73. 
Garvey, A. M., Germann, F., \& Bolton, L. E. (2016). Performance Brand Placebos: How Brands Improve Performance and Consumers Take the Credit. Journal of Consumer Research, 42(6), 931-951. https://doi.org/10.1093/jcr/ucv094

Howe, N., \& Strauss, W. (2000). Millennials rising: the next great generation. New York: Vintage Books.

Kakati, R. P., \& Choudhury, S. (2013). Measuring Customer-Based Brand Equity Through Brand Building Blocks for Durables. IUP Journal of Brand Management, 10(2), 24-41.

Kapferer, J.-N. (2005). The new strategic brand management. London: Kogan-Page.

Kaplan Thaler, L., \& Koval, R. (2003). Bang! Getting your message heard in a noisy world. New York: Currency.

Keller, K. L. (2009). Building strong brands in a modern marketing communications environment. Journal of Marketing Communications, 15(2/3), 139-155. https://doi.org/10.1080/13527260902757530

Keller, K. L., Heckler, S. E., \& Houston, M. J. (1998). The Effects of Brand Name Suggestiveness on Advertising Recall. Journal of Marketing, 62(1), 48-57. https://doi.org/10.2307/1251802

Kellison, T. B., Yu Kyoum, K., \& Magnusen, M. J. (2013). The Work Attitudes of Millennials in Collegiate Recreational Sports. Journal of Park \& Recreation Administration, 31(1), 78-97.

Labrecque, L. I., Krishen, A. S., \& Grzeskowiak, S. (2011). Exploring social motivations for brand loyalty: Conformity versus escapism. Journal of Brand Management, 18(7), 457-472. https://doi.org/10.1057/bm.2011.12

Lam, S. K., Ahearne, M., Hu, Y., \& Schillewaert, N. (2010). Resistance to Brand Switching When a Radically New Brand Is Introduced: A Social Identity Theory Perspective. Journal of Marketing, 74(6), 128-146. https://doi.org/10.1509/jmkg.74.6.128

Lambert-Pandraud, R., \& Laurent, G. (2010). Why Do Older Consumers Buy Older Brands? The Role of Attachment and Declining Innovativeness. Journal of Marketing, 74(5), 104-121. https://doi.org/10.1509/jmkg.74.5.104

Liu-Thompkins, Y., \& Tam, L. (2013). Not All Repeat Customers Are the Same: Designing Effective Cross-Selling Promotion on the Basis of Attitudinal Loyalty and Habit. Journal of Marketing, 77(5), 21-36. https://doi.org/10.1509/jm.11.0508

Lotfizadeh, F., \& Lotfizadeh, F. (2015). Comparing High-involvement and Low-involvement Products: Brand Perspective. International Journal of Management, Accounting \& Economics, 2(5), 404-413.

Maity, M., \& Gupta, S. (2016). Mediating Effect of Loyalty Program Membership on the Relationship Between Advertising Effectiveness and Brand Loyalty. Journal of Marketing Theory \& Practice, 24(4), 462-481. https://doi.org/10.1080/10696679.2016.1205450

Mostert, P. G., Petzer, D. J., \& Weideman, A. (2016). The interrelationships between customer satisfaction, brand loyalty and relationship intentions of Generation Y consumers towards smart phone brands. South African Journal of Business Management, 47(3), 25-34. https://doi.org/10.4102/sajbm.v47i3.65

Putre, L. (2013). The March of the Millennials. H\&HN: Hospitals \& Health Networks, 87(9), 38-42.

Raut, U. R. (2015). A Study on Brand Loyalty and Its Association with Demographics of Consumers: Evidence from the Cellphone Market of India. IUP Journal of Brand Management, 12(3), 30-44.

Reisenwitz, T., \& Gupta, S. (2016) Brand Loyalty and Store Loyalty for Consumers Purchasing A Product Warranty In A Healthcare Setting: An Investigation of The Differences Across Gender, Age, And Income Groups. Journal of Business Strategies, 33(1), Spring, 1-14.

Russell, B. (2015). The Millennial Shift in Hotel Brands. HVS Global Hospitality Report, 5-7.

Saddlemyer, J., \& Bruyneel, S. (2016). Brand Logo Salience as a Signal of Brand Status. Advances in Consumer Research, 44, 607-608.

Smilansky, O. (2016). GENERATION Y: In Control, Content, and Community-Minded. (Cover story). CRM Magazine, 20(2), 20-24.

Smith, K. (2011, September). Digital marketing strategies that Millennials find appealing, motivating, or just annoying. Journal of Strategic Marketing, 19(6), 489-499. Business Source Premier, Ipswich, MA. https://doi.org/10.1080/0965254X.2011.581383 
Solomon, M. (2016). 2015 Is the Year of The Millennial Customer: 5 Key Traits These 80 Million Consumers Share.

Stocchi, L., Driesener, C., \& Nenycz-Thiel, M. (2015). Brand image and brand loyalty: Do they show the same deviations from a common underlying pattern? Journal of Consumer Behavior, 14(5), 317-324. https://doi.org/10.1002/cb.1522

Van der Lans, R., Pieters, R., \& Wedel, M. (2008). Competitive Brand Salience. Marketing Science, $27(5), 922-931$. https://doi.org/10.1287/mksc.1070.0327

Von Freymann, J. W. (2006). Age and Generational Cohort Effects in Store Assessments and Choice: A Case Study. Marketing Management Journal, 16(2), 203-222.

Yu-Ping, C., Nelson, L. D., \& Ming, H. (2015). From "Where" to "What": Distributed Representations of Brand Associations in the Human Brain. Journal of Marketing Research (JMR), 52(4), 453-466. https://doi.org/10.1509/jmr.14.0606 